\title{
Julian Degen. "Deportationen zur Zeit der ersten persischen Eroberung Ägyptens. Kambyses' Sicherungspolitik im Lichte hellenischer und achaimenidischer Quellen"
}

\section{Reinhard Pirngruber}

\section{(2) OpenEdition}

\section{Journals}

Electronic version

URL: https://journals.openedition.org/abstractairanica/51733

DOI: $10.4000 / a b s t r a c t a i r a n i c a .51733$

ISSN: 1961-960X

Publisher:

CNRS (UMR 7528 Mondes iraniens et indiens), Éditions de l'IFRI

Electronic reference

Reinhard Pirngruber, "Julian Degen. "Deportationen zur Zeit der ersten persischen Eroberung Ägyptens. Kambyses' Sicherungspolitik im Lichte hellenischer und achaimenidischer Quellen"', Abstracta Iranica [Online], Volume 42-43 | 2021, document 5, Online since 30 December 2020, connection on 24 December 2022. URL: http://journals.openedition.org/abstractairanica/51733 ; DOI: https://doi.org/10.4000/abstractairanica.51733

This text was automatically generated on 24 December 2022.

All rights reserved 


\section{Julian Degen. "Deportationen zur} Zeit der ersten persischen Eroberung Ägyptens. Kambyses' Sicherungspolitik im Lichte hellenischer und achaimenidischer Quellen"

Reinhard Pirngruber 


\section{REFERENCES}

Julian Degen. "Deportationen zur Zeit der ersten persischen Eroberung Ägyptens.

Kambyses' Sicherungspolitik im Lichte hellenischer und achaimenidischer Quellen" in R. Rollinger, H. Stadler (eds.). 700 Millionen Jahre Migrationsgeschichte. Annäherungen zwischen Archäologie, Geschichte und Philologie. Innsbruck: Innsbruck University Press, 2019, p. 183-217

1 The contribution discusses Achaemenid deportation policies as exemplified by the case of the Egyptians. The central argument, based on readings of Herodotus and Ctesias, is that the central aim of the deportations in the aftermath of Cambyses' conquest of the country was the stabilisation of Achaemenid rule. This was to be achieved by transplanting a significant number of the notoriously rebellious mákhimoi of Lower Egypt, local warlords, into the empire's core region; thereby removing them from their power base. The second part briefly discusses Egyptian workers (kurtaš), both specialized and unskilled, in the Persepolis archives and according to Achaemenid royal inscriptions.

\section{AUTHORS}

REINHARD PIRNGRUBER

Institut für Orientalistik, Wien 